Revue bibliographique pour le domaine irano-aryen

\title{
Rémy Boucharlat. « Les traces archéologiques des palais achéménides de Hamadan »
}

\section{Astrid Nunn}

\section{(2) OpenEdition}

1 Journals

\section{Édition électronique}

URL : http://journals.openedition.org/abstractairanica/49343

DOI : 10.4000/abstractairanica.49343

ISBN : 1961-960X

ISSN : 1961-960X

Éditeur :

CNRS (UMR 7528 Mondes iraniens et indiens), Éditions de l'IFRI

Référence électronique

Astrid Nunn, «Rémy Boucharlat. "Les traces archéologiques des palais achéménides de

Hamadan » », Abstracta Iranica [En ligne], Volume 40-41 | 2019, document 49, mis en ligne le 30

octobre 2019, consulté le 17 avril 2021. URL : http://journals.openedition.org/abstractairanica/49343

DOI : https://doi.org/10.4000/abstractairanica.49343

Ce document a été généré automatiquement le 17 avril 2021.

Tous droits réservés 


\title{
Rémy Boucharlat. « Les traces archéologiques des palais achéménides de Hamadan »
}

\author{
Astrid Nunn
}

\section{RÉFÉRENCE}

Rémy Boucharlat. « Les traces archéologiques des palais achéménides de Hamadan ». Arta 2018.002, 35 p. (http://www.achemenet.com/pdf/arta/

ARTA_2018.002_Boucharlat.pdf)

1 L'existence de palais achéménides à Hamadan est assurée par plusieurs dizaines de fragments de bases de colonnes, de tambours de colonnes et de chapiteaux en pierre. Certaines pièces proviennent de la colline au nord-est du centre de la ville moderne, le Tepe Hegmataneh. Pourtant, les fouilles reprises en 1983 sur cette colline n'ont pas révélé de quartier royal achéménide. L'on sait maintenant que ces fragments sont des réemplois de l'époque parthe. Le centre achéménide doit donc se trouver ailleurs, peutêtre dans la seconde colline de Hamadan, le Tepe Mosalla.

2 L'A. débute par un bref aperçu historique de la ville de Hamadan. Son importance est bien établie avant les Mèdes, et malgré le manque de traces archéologiques, l'on sait qu'elle était également importante sous les Grands Rois. Suivt une description des découvertes archéologiques faites depuis le XIXème s. avec une compilation de tous les fragments archéologiques connus, leur lieu de découverte, leur type et leur module. La plupart ont déjà été publiés, mais souvent dans des publications en persan ou difficilement accessibles. La pierre vient d'une carrière toute proche.

3 La diversité des types et modules laisse supposer plusieurs salles hypostyles, dont les colonnes avaient des fûts en bois et parfois en pierre. Au moins deux salles devaient avoir des colonnes en pierre. Cette diversité - tel l'emploi simultané de bases rondes et carrées - se retrouve entre autre à Karačamirli, en république d'Azerbaijan, palais non 
royal mais d'un haut personnage régional. Cette disparité serait donc plutôt un signe de médiocrité provinciale. De plus les modules de Hamadan sont plus petits qu'à Suse et Persépolis. Toutefois, si l'architecture achéménide de Hamadan ne peut pas rivaliser avec celle de Persépolis, elle peut être comparée à celle de Suse et était certainement supérieure à celle de Babylone. Elle peut également être comparée à Karačamirli, dont le palais compte au moins huit salles à bases de colonnes en pierre.

\section{AUTEURS}

\section{ASTRID NUNN}

Université de Munich 